ISBN 978-93-84468-80-4

International Conference on Agricultural, Biological and Environmental Sciences

(ICABES-2016)

Pattaya (Thailand) Dec. 14-16, 2016

\title{
Ecosystem Assessment of Sumatra Undisturbed Natural Tropical Forest
}

\author{
Budi Utomo ${ }^{1}$, Afifuddin Dalimunthe ${ }^{1}$, Eddy Marlianto ${ }^{2}$ and Christovorus Sihotang ${ }^{1}$ \\ ${ }^{1}$ Forestry Faculty, University Sumatra Utara, Medan, 20152, Indonesia \\ ${ }^{2}$ Mathematics and Nature Science Faculty, University Sumatra Utara, Medan, 20152, Indonesia \\ Jl. Tridharma Ujung No. 1 Kampus USU Medan, North Sumatra Indonesia, Telp. +6261-8201920 \\ Corresondence Author: budi2@usu.ac.id
}

\begin{abstract}
This research was conducted at The Simpulan Angin Forest in Deli Serdang Regency, North Sumatra Province, Indonesia. The study aimed to determine the condition of the vegetation and the undisturbed natural forest canopy. This study was a first step to assess what was happening in the natural forests so as to prevent flooding when it rains. Factors that observed in this study were the species composition, vegetation stratum, canopy of 12 samples of tree canopies and lateral roots, up to the thickness of humus forest in 50 sample plots. The results showed that there were 5 stratum of forests in this forest which were able to inhibit the precipitation rate and as well as the humus of forest that has an average thickness of $10 \mathrm{~cm}$ that serves as a gigantic sponge that can absorb rain water up to 650,000 tons of rain water and release it slowly into the soil to move by infiltrating forming ground water.
\end{abstract}

Keywords: undisturbed forest, lateral roots, stratum, forest humus

\section{Introduction}

\section{Background}

Today almost all urban areas in Indonesia often suffered a flood disaster that emerged during the rainy season. This does not happen in times past where the population density was still rare. Flood hit areas many urban centers, disrupting public because inundate settlements, the administrative center, and trade centers.

Flooding occurs because the amount of rain received is greater than the soil's ability to absorb water and rain water disposal capacity through ditches and streams in the region. The amount of population growth in urban areas up buildings, a factor that affects the occurrence of floods in urban areas. The establishment of buildings in urban areas reducing infiltration process, thereby increasing the flow of water run off.

The growth of population density continues to increase rapidly, especially in urban areas prone to floods during the rainy season initiated this research to study the hydrological processes that occur in natural forests. The procedure for treating water forests need to be studied to determine how the forest receive rains, retains and infiltrates into the ground so that flooding does not occur.

Simpulan Angin Forest is a natural forest is preserved and is still considered sacred by the people who dwelt in the surrounding forest. Community of Perkentangen Village as one of the villagers who are directly adjacent to the forest. the public believes that if the state of the forest is maintained it will also give a good impact on the situation of those living in areas immediately adjacent to the forest. Community of Perkentangen Village understand if the Simpulan Angin Forest was still maintained continuity, the agricultural land they have will still be protected from various disasters, landslides and flooding and disruption of existing animals in the forest. 


\section{Methods}

The research was conducted in June and August 2016. The study was conducted in The Simpulan Angin Forest in Deli Serdang Regency administration area. The tools used in this study were machetes, hoes, meter, walking stick, digital camera, GPS, plastic rope, stationery, tally sheet, 80 mesh sieve, digital balance, and oven.

\section{Research Procedure}

Analysis of Vegetation

Vegetation analysis performed in this study using the track, which consists of five lines. The distance between lines of 200 meters. Plots in each lane consists of five plots with a distance of $50 \mathrm{~m}$ between plots. Plots are arranged in a nested which was divided in four sizes, $20 \times 20 \mathrm{~m}$ to the level of a tree, $10 \times 10 \mathrm{~m}$ for poles, $5 \mathrm{x}$ $5 \mathrm{~m}$ for saplings, and $2 \times 2 \mathrm{~m}$ for seedlings, grass, shrubs and other undergrowth. The data obtained were then analyzed by counting: density $(\mathrm{K})$; relative density $(\mathrm{KR})$; frequency; relative frequency (FR); dominance (D); relative dominance (DR); and the importance value index (IVI).

\section{Length of Lateral Root}

Lateral root length measurements performed on 12 samples of trees that have been selected to represent each type of tree that grows in The Simpulan Angin Forest. Trees samples have been choosen then measured the diameter of the trunk, height branch-free trunk, canopy height and width of the canopy and then proceed with digging of lateral roots of each tree sampled.

\section{Humus Thickness}

Forest humus thickness measured across a swath of the plots sample in each lane. Thus there are 50 sample thickness measurement humus. Furthermore taken $200 \mathrm{~g}$ of humus plot $^{-1}$ to calculate the water absorption capability. Each sample was then screened at 80 mesh sieve and each of its $100 \mathrm{~g}$ soaked in water. After a while humus drained and put into the cup and put in oven for $2 \times 24$ hours later weighed.

\section{Results And Discussion}

\section{The Species Composition}

Based on the analysis of vegetation around the research plot of 4 ha at an altitude of 950-1100 meters above sea level in all type and forest condition found 159 species of plants consisting of 84 plant species of grass/shrub and undergrowth, and 75 species of trees. The calculations show that the individual density of plants per hectare is: 88.800 individual grass/shrub/undergrowth, 16,600 individual seedlings, 3,780 individuals sapling, 576 individuals pole, and 220 individual trees.

TABLE I Data density and important value index in the three dominant plant species at the level of grass / shrub, seedling, sapling, pole and tree per hectare in The Simpulan Angin Forest

\begin{tabular}{lllrr}
\hline \multicolumn{1}{c}{ Growth level } & Species & Family & Density & IVI \\
\hline \multirow{2}{*}{ Grass/shrub/ } & Procris frutescens & Araliaceae & 9,600 & 24.80 \\
undergrowth & Elatostema nigrescens & Urticaceae & 4,500 & 17.98 \\
& Hedychium roxburghii & Zingiberaceae & 3,400 & 11.03 \\
Seedling & Sapium baccatum & Euphorbiaceae & 1,375 & 25.43 \\
& Strombosia javanica & Olacaceae & 1,120 & 22.32 \\
& Schima wallichi & Theaceae & 532 & 18.68 \\
Sapling & Sapium baccatum & Euphorbiaceae & 224 & 19.04 \\
& Altingia excelsa & Altingiaceae & 192 & 17.17 \\
& Dacryodes rugosa & Burseraceae & 108 & 15.98 \\
Pole & Lithocarpus elegans & Fagaceae & 78 & 32.54 \\
& Sapium baccatum & Euphorbiaceae & 56 & 26.59 \\
& Dacryodes rugosa & Burseraceae & 45 & 23.74 \\
Tree & Dacryodes rugosa & Burseraceae & 25 & 49.70 \\
& Lithocarpus elegans & Fagaceae & 15 & 42.96 \\
& Dacrycarpus imbricatus & Podocarpaceae & 22 & 23.67 \\
\hline
\end{tabular}

Remarks: IVI = important value index 
The result showed that the undergrowth was dominated by Procis frutescens, Elatostema nigrescens and Hedychium roxburghii with each IVI of 24.80, 17.98 and 11,03. Seedlings dominated by Sapium baccatum, Strombosia javanica and Schima wallichi. Growth level of saplings was dominated by Sapium baccatum, Altingia excelsa and Dacryodes rugosa. At the level of the pole, tree dominated by Lithocarpus elegans, Sapium baccatum and Dacryodes rugosa. At the level of the trees, plants dominated by Dacryodes rugosa, Lithocarpus elegans and Dacrycarpus imbricatus (Table 1). From Table 1 it can be seen that in general there was consistency dominant plant species ranging from the growth level of seedlings to the tree level. Some plants trees reflected the dominant level has also emerged as the predominant type in tree saplings and seedlings level. This shows The Simpulan Angin Forest was still quite good and has not been disrupted due to the consistency of the type that does not cut off from the tree to it saplings and seedlings.

According Kuswandi, et al (2015) dominance types can be seen from the important value index (IVI). The types that have the highest IVI has a great opportunity to be able to maintain the sustainability of its kind. Dominance types also showed good adaptability and good interaction with the components of the ecosystem in which it grows. Pratiwi and Garsetiasih (2007) states that ecological forest vegetation communities is determined by a function of the dominant species. which is the result of the interaction of the components contained in these ecosystems.

From the ecosystem point of vew, Silalahi (1992); and Ernayati and Juliaty (2007) stated that the most important thing of this is the concept of ecosystem ecology. Ecosystem is an ecological system formed by a reciprocal relationship between living organisms with their environment. In this system all components work regularly as a whole.

The results of the analysis of vegetation made at all levels showed the growth The Simpulan Angin Forest has 5 Stratum layers that made up the forest canopy in the Stratum A, B, C, D and E. The entire stratum works in inhibiting the precipitation rate so that the rainwater that falls to the forests floor will fall gradually and slowly. Stratum layers serves to hold and reduce the discharge of rain so it does not directly fall onto the surface of the forest floor.

\section{Length of Lateral Root}

Observations lateral root length were performed on samples representing 12 tree species in The Simpulan Angin Forest. Observations done descriptively by measuring the length of each horizontal lateral roots, bole height, trunk diameter, canopy height and width of the tree canopy on each sample (Table 2).

TABLE II Data of 12 Trees Sample in The Simpulan Angin Forest

\begin{tabular}{|c|c|c|c|c|c|c|}
\hline Species & Family & $\begin{array}{l}\text { Bole } \\
\text { Height } \\
(\mathrm{m})\end{array}$ & $\begin{array}{l}\text { Trunk } \\
\text { Diameter } \\
\text { (cm) }\end{array}$ & $\begin{array}{l}\text { Canopy } \\
\text { Height } \\
(\mathrm{m}) \\
\end{array}$ & $\begin{array}{l}\text { Canopy } \\
\text { Width } \\
(\mathrm{m}) \\
\end{array}$ & $\begin{array}{c}\text { Lateral } \\
\text { root length } \\
(\mathrm{m})\end{array}$ \\
\hline Strombosia javanica & Olacaceae & 10 & 50 & 15 & 9.5 & 10.7 \\
\hline Schima wallichi & Theaceae & 11 & 66 & 18 & 6.5 & 7.8 \\
\hline Sapium baccatum & Euphorbiaceae & 9.4 & 35 & 17.4 & 7.7 & 8.9 \\
\hline Altingia excelsa & Altingiaceae & 9 & 30 & 14 & 6.3 & 7.6 \\
\hline Canarium littorale & Burseraceae & 15 & 32 & 24 & 9 & 10.2 \\
\hline Dacrycarpus imbricatus & Podocarpaceae & 17 & 65 & 25 & 8.5 & 9.3 \\
\hline Lithocarpus elegans & Fagaceae & 8 & 50 & 19 & 11 & 12.1 \\
\hline Dacryodes rugosa & Burseraceae & 17 & 68 & 29 & 7.5 & 8.7 \\
\hline Castanopsis motleyana & Fagaceae & 9.5 & 48 & 15.5 & 5 & 6.7 \\
\hline Porterandia anisophylla & Rubiaceae & 8.4 & 27 & 16.4 & 4 & 5.4 \\
\hline Actinodaphne glomerata & Lauraceae & 16 & 56 & 25 & 7.2 & 8.1 \\
\hline Shorea gibbosa & Dipterocarpaceae & 14 & 40 & 22 & 5.4 & 6.1 \\
\hline
\end{tabular}

The result of the calculation of the 12 trees sampled was found that in 12 samples of tree crown width and length turned out to be the root of each tree does not differ much. As an example for this type of Strombosia javanica which has rod diameter $50 \mathrm{~cm}$ and canopy width $9.5 \mathrm{~m}$. It turns out the lateral roots length was $10.7 \mathrm{~m}$. Similarly to other types of plants that have a crown width and length of the roots are not much different. This shows that the fertility of the soil of the forest floor is quite good and has not been disturbed. According Utomo (2008) on infertile soil tree roots will tend to lengthen its roots as an effort to find nutrients for normal growth. In less fertile soil in lowland forests of North Sumatra. Length of lateral tree roots Artocarpus communis 25 year old with a trunk diameter of $60 \mathrm{~cm}$ can reach $15 \mathrm{~m}$. whereas only $8 \mathrm{~m}$ width of the canopy.

According to Gardner, et al. (1991) roots are the main vegetative organs which supplies water, mineral and materials that are essential for plant growth and development. Although its function is very important, it is often 
very little research on the roots due to the high level of difficulty in extracting and observations. Lakitan (1991) states that the root is the gateway for nutrients and water from the soil which is very important for the physiological processes of trees, so the availability of adequate water supply from forest humus greatly affect the state of the roots. According to Song Ai and Torey (2013) at the time of water shortages root system growth will generally increase, while the growth of the canopy decreases.

\section{The Thickness of The Forest Humus}

The results of measuring the thickness of humus on the forest Wind Knot performed on the entire sample plots were contained in five lines presented in the form of a bar chart (Figure 1). The results of the measurement of the thickness of the forest humus in Figure 1 shows that the thickness of the humus found in each sample plots were quite diverse. The thickness of the humus of the highest found in the path of the two plots which amounted to $13 \mathrm{~cm}$. while the thickness of the lowest forest humus found on two plots three lanes. three plot lines five and five plot lines two and five which is equal to $7 \mathrm{~cm}$. Thus it can be said that in the forest humus knot winds average thickness reaches $10 \mathrm{~cm}$.

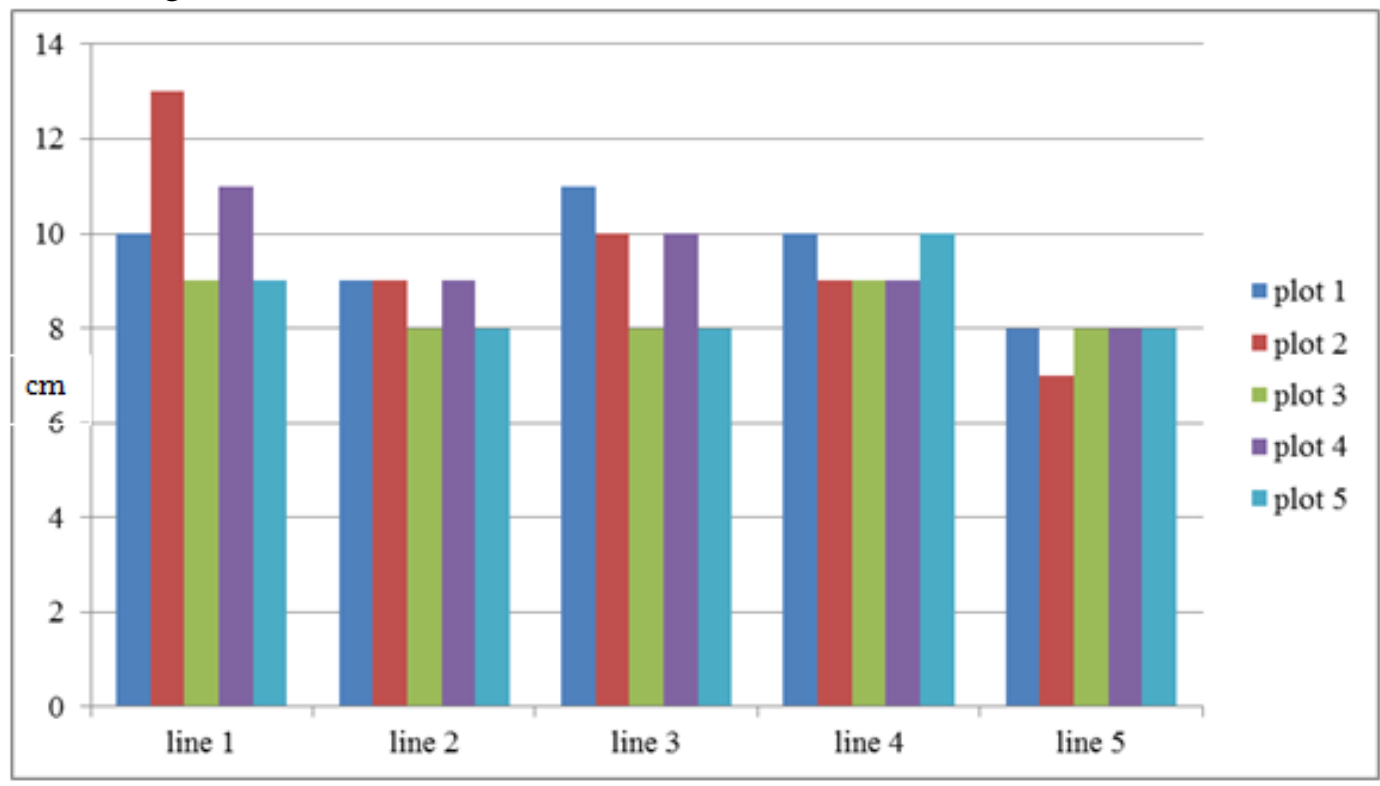

Fig. 1 Graph thickness Forest Humus

Primary succession process that lasted thousands of years without human interference will result in both naturally growing forests. This will result in closed nutrient cycle in forests takes place without interruption. Leaves, twigs and stems of the vegetation of the entire stratum of dead will decompose naturally formed humus that provides sufficient nutrients for the development of the next forest. Vegetation growing in the past will be a precursor to the development of forest humus in the next period. According to Hakim, et al. (1986) humus is a complex compound somewhat resistant to weathering. brown. kolodial amorphous nature and derived from plant or animal tissue that has been modified and synthesized by a variety of microorganisms. Furthermore Yamani (2010) states that the type and number of plants also contribute to the amount of nutrients available humus, both physically and chemically as well as contribute to the fertility of the soil underneath.

Availability of forest humus as a constituent of adequate forest will provide added value to the forest ecosystem. Kuswanda and Antoko (2008) state forest serves as a container karbondoksida (carbon dioxide sink), wildlife habitat, hydrological flow modulators, and soil conservers is one aspect of the biosphere of the earth's most important. As the forest humus hydrological flow modulator capable of storing water reserves that are needed by plants to meet the water needs of plants. Nopandry, et al (2005) states that the humus is part of the composition of the forest which has its own function in maintaining the balance of forest nature. Without humus, the forests would lose its function in maintaining the stability of the hydrological cycle and soil nutrient cycling.

\section{Water Absorption of Humus}

The results of the measurement of the ability of water absorption by humus forest performed three repetitions are presented in Table 3. Early in the third repeat of the mass of forest humus which tested the ability of water absorption is $100 \mathrm{~g}$ before the water soaked to saturation. 
TABLE III Data Capabilities Water Absorption By Humus

\begin{tabular}{lllll}
\hline Repeatition & $\begin{array}{l}\text { Wet Weight } \\
(\mathrm{g})\end{array}$ & $\begin{array}{l}\text { Oven Dry Weight } \\
(\mathrm{gr})\end{array}$ & $\begin{array}{l}\text { the difference in weight } \\
(\mathrm{gr})\end{array}$ & $\begin{array}{l}\text { Percentage } \\
(\%)\end{array}$ \\
\hline 1 & 123.36 & 16.50 & 106.85 & 647.47 \\
2 & 123.03 & 16.33 & 106.70 & 653.34 \\
3 & 116.96 & 15.85 & 101.10 & 637.69 \\
\hline
\end{tabular}

From 3 repetitions of weight humus turns out not much different, ie ranging from $116.96 \mathrm{~g}$ to $123.36 \mathrm{~g}$, and after being dried in oven became 15.85-16.50 g. This means having the ability humus water absorption average of $646.16 \%$ or 6.5 times of its dry weight. Assuming an average thickness of humus forest is $10 \mathrm{~cm}$ and a bulk density of humus is $0.5 \mathrm{~g} \mathrm{~cm}^{-3}$, then in each hectare of topsoil forests can absorb water up to 650,000 tons of water every time it rains. This is thought to be one cause of forest were able to keep the cycle hydrological so there is no flooding. This is contrary to the city forest that does not have a stratum and humus so the runoff caused by rain to be very fast.

\section{Conclusion}

A state of good forest and undisturbed composed of a variety of factors that include the stratum into the roof of the forest and forest humus as the forest floor that acts far water discharge during the rains so far runoff and prevent flooding in the forest.

Lateral length on forest trees undisturbed situation is not much different from the width of the canopy because the supply of water and nutrients needed by plants through lateral roots are still met.

\section{Acknowledgements}

On this occasion the authors would like to thank the ministry of research and technology and higher education on grants that have been given to support this research.

\section{References}

[1] Ernayati and Juliaty. N. 2007. Diversity Level Type Stake in Former Region Logging with Conventional Systems and RIL in PT. INHUTANI Labanan. Journal of Forest Research and Nature Conservation 4(2): 183-193.

[2] Gardner FP, R Brent and LM Roger. 1991. Plant Raise Physiology. University Indonesia

[3] Hakim N, MY Nyakpa, AM Lubis, SG Nugroho, MR Saul, MA Diha, GB Hong and HH Bailey. 1986. Fundamentals of Soil Science. Publisher University of Lampung. Lampung.

[4] Kuswandi R, $R$ Sadono, $N$ Supriyatno and D Marsono. 2015. Diversity of Natural Forest Stand Structure Used Felling Based Papua Biogeography. Journal of Humans and The Environment 22(2): 151-159.

[5] Kuswanda. W and B Antoko. 2008. Biodiversity of Plants at Various Types of Forests to Support Wilderness Zone Management in Batang Gadis National Park. Journal of Forest Research and Nature Conservation 5(4): 337-354.

[6] Lakitan B. 1991. Physiology Plant Growth and Development. Rajawali press.

[7] Nopandry B, ZA Pian and Rahmawaty. 2005. Intake of Forest Humus by Community. Peronema Forestry Science Journal 1: 1-8.

[8] Pratiwi and Garsetiasih. 2007. Soil Physical and Chemical Properties And Composition of Vegetation in Natural Park Tangkuban Perahu. West Java Province. Journal of Forest Research and Nature Conservation 4(5): 110-117.

[9] Silalahi D. 192. Environmental Law in The Enforcement of Law Environmental System In Indonesia. Alumni Publisher. Bandung.

[10] Song Ai, N and P Torey. 2013. Morphological Characters Roots as an Indicator of a Lack of Water in Plants. Journal Bioslogos 3(1): 31-39.

[11] Yamani A. 2010. Assessment Level of Soil Fertility In Mountain Protection Forest Sebatung in Kotabaru District, South Kalimantan. Journal of Tropical Forests 11(29):32-37. 